INTERNATIONAL JOURNAL OF RESEARCHES IN BIOSCIENCES, AGRICULTURE AND TECHNOLOGY (c) VISHWASHANTI MULTIPURPOSE SOCIETY (Global Peace Multipurpose Socie ty) R. No. MH-659/13 (N) www.vmsindia.org

\title{
IN VITRO CULTURE MEDIATED ENHANCED ALKALOID PRODUCTION IN DATURA METEL L. UNDER HIGH SALT CONCENTRATIONS.
}

\author{
V. S. Kale \\ De partment of Botany, New Arts, Commerce and Science College, Ahmednagar - 414001. \\ vijayk_nsk@rediffmail.com
}

\begin{abstract}
:
Tropane alkaloids is pharmaceutically one of the important class of alkaloids. Atropine, scopolamine and hyoscine are important among them. Atropine and scopolamine are used to a large extent in ophthalmic practice. Atropine is used as an antidote. It is one of the widely used safest antidote. Tropane alkaloids are also use d as an important ingredient in various avurve dic preparations. Earlier Atropa belladona was used as the ultimate source of tropane alkaloids. Howe ver in present time Datura metel is use d as an alternate source of the se alkaloids as Atropa be came scare. Datura metel L. is an annual indigenous herb. Its leaves contain about 0.5 per cent alkaloids chiefly scopolamine (hyoscine) with traces of hyoscyamine and atropine.

In the present investigation callus from three different explants of $D$. metel viz. petiole, leaf and nodal sector were cultured on MS medium containing NAA, kinetin and their combinations. Highest and earliest callusing (40 days) was observed on the medium containing 2, 4-D (1 mg/l) + Kinetin (1mg/1). Highest callus formation with petiole explants was observed in MS medium supplemented with 2, 4-D (2 mg / $)$. Enhancement in alkaloid production was noticed up to $7.5 \mathrm{mM}$ concentrations of $\mathrm{NaCl}$ and $\mathrm{Na}_{2} \mathrm{SO}_{4}$ salts. However at higher concentrations of both the salts. there was considerable decrease in the alkaloid content

Keywords: Datura metel, ge rmination, callus culture.
\end{abstract}

\section{Introduction}

Narcotic and intoxicating properties of Datura are long been familiar to Indians. D. metel L. is an annual indigenous herb. Datura leaves contain about 0.5 per cent alkaloids chiefly scopolamine (hyoscine) with traces of hyoscyamine and atropine. Atropine and scopolamine are used to a large extent in ophthalmic practice (Trease and Evans, 1985). During the two world wars Datura was brought to some prominence as possible source of those alkaloids when other solanaceous drugs especially Atropa belladonna become scare. It is also used as an important ing redient in various ayurvedic preparations (Jaggi et al.1989).

Due to present investigation it became possible to ascertain percent synthesis of secondary metabolites under controlled conditions for which the Datura is known so far (Muthukumar et al. 2001). Attempts were made to enhance the productivity in terms of secondary metabolites by creating artificial salt stress in the culture medium. It is noteworthy that presently most of the atropine used in Indian pharmaceuticals is imported.

\section{Material and Methods CALLUS CULTURE:}

Mature seeds of D. metel were collected from plants grown in botanical garden of the college. Seeds were properly surface ste rilized by following standard method (De, 1992) and treated with fungicide. Surface ste rilized seeds were inoculated in culture bottles over Murashige and Skoog (1962) basal medium without growth regulators and germinated. Three different explants viz. petiole; leaf and nodal sector obtained from 30 days old plantlet were cultured on MS medium containing NAA, Kinetin and their combinations. Highest and earliest callusing (40 days) were observed on the medium containing 2, 4-D (1mg/1) + Kinetin $(1 \mathrm{mg} / \mathrm{l})$. Various concentrations of growth substances were tried by using variable explants. Callus proliferation was observed at 2 , $4-\mathrm{D}(2 \mathrm{mg} / \mathrm{l})+\mathrm{Kin}(2 \mathrm{mg} / 1)$ in the medium. Highest callus formation was obse rved in petiole explants.

\section{ALKALOID PRODUCTION:}

Callus obtained from the petiole of the medium supplemented with 2, 4-D (2 mg/1) (highest callus formation concentration) was sub cultured on the same composition of the medium suppleme nted with the salts.

\section{SALT TREATMENT:}

In order to create salt stress medium was supplemented with various concentrations of $\mathrm{NaCl}$ and $\mathrm{Na}_{2} \mathrm{SO}_{4}$. The salt treatment includes a series of increasing concentrations $(2.5,5.0$, $7.5,10.0,12.5,15.0,17.5$ and $20.0 \mathrm{mM}$ ) of both the sodium chloride and sodium sulphate salts separately. Forty days old callus was harvested for the estimation of alkaloid contents. The quantitative estimation of alkaloids in different molar concentrations was done spectrophotometrically by following Vitali- Morin reaction modified by Freeman (1955) and the alkaloid content was calculated as the amount of hyoscine on the basis of dry weight of the callus material. 
Statistical Analysis:

All the experiments were repeated thrice by maintaining 10 replicates each. significance of effects of treatments was determined by using analysis of variance (ANOVA) followed by $\operatorname{DMRT}(\mathrm{P} \leq 0.05)$ to determine significant diffe re nces among means.

\section{Results and Discussion: \\ Effect of PGR on Callus Culture:}

Observations on the amount of callus produced at various combinations of PGR's show that, the highest callus formation ( $7.26 \pm 1.1 \mathrm{gm} \mathrm{F.W.)} \mathrm{with} \mathrm{petiole} \mathrm{explants} \mathrm{was}$ observed in MS medium (Table -1) supplemented with 2, 4-D and Kinetin (2 mg /1). However leaf explants were found to moderate and nodal sector produced least amount of the callus.
It was found that, there was enhancement in callus formation in all explants when grown on both 2,4-D and Kinetin in combinations. Less callus formation was noticed when all explants we re grown either on 2,4-D or Kinetin. Increased rate of callus formation was observed when all explants were grown on MS medium supplemented with $2 \mathrm{mg} / 1$ 2,4-D and Kinetin separately.

Effects of Salts on Alkaloid Production:

Results on the total alkaloid content (Table 2, Fig. I) revealed that alkaloid content increased over the control in the callus grown up to $7.5 \mathrm{mM}$ of both the salts. However it decreased at all higher concentrations the reafter. The results obtained (Table 2) shows that, incorporation of increased concentration of stress inducing $\mathrm{NaCl}$ and $\mathrm{Na}_{2} \mathrm{SO}_{4}$ in the medium up to $7.5 \mathrm{mM}$ resulted into higher accumulation of alkaloids of each $\mathrm{NaCl}$ and $\mathrm{Na}_{2} \mathrm{SO}_{4}$.

Table 1. Effect of different combinations (mg/l) of 2, 4-D and Kinetin added to MS medium on fresh weight production of callus of petiole, leaf and nodal sectors in Datura metel L.

\begin{tabular}{|c|c|c|cc|c|}
\hline Sr. No. & \multicolumn{3}{|c|}{ Growth Substances (mg/l) } & \multicolumn{3}{|c|}{ Fresh Weight (g) of Explants Used } \\
\hline & $2,4-\mathrm{D}$ & Kin & Petiole & Leaf & Nodal Se ctor \\
& & & & & \\
\hline 1 & 0 & 1 & $1.92 \pm 0.1$ & $1.64 \pm 0.1$ & $0.89 \pm 0.1$ \\
\hline 2 & 0 & 2 & $2.79 \pm 0.4$ & $2.30 \pm 0.3$ & $0.95 \pm 0.3$ \\
\hline 3 & 0 & 3 & $2.03 \pm 0.2$ & $1.90 \pm 0.6$ & $0.78 \pm 0.2$ \\
\hline 4 & 1 & 0 & $0.47 \pm 0.1$ & $0.32 \pm 0.2$ & $0.29 \pm 0.1$ \\
\hline 5 & 2 & 0 & $0.31 \pm 0.1$ & $0.27 \pm 0.1$ & $0.21 \pm 0.1$ \\
\hline 6 & 3 & 0 & $0.23 \pm 0.1$ & $0.19 \pm 0.0$ & $0.14 \pm 0.0$ \\
\hline 7 & 1 & 1 & $6.23 \pm 0.9$ & $4.11 \pm 0.4$ & $2.15 \pm 0.3$ \\
\hline 8 & 2 & 2 & $7.26 \pm 1.1$ & $3.80 \pm 0.2$ & $2.86 \pm 0.2$ \\
\hline 9 & 3 & 3 & $6.89 \pm 0.8$ & $2.89 \pm 0.4$ & $2.10 \pm 0.2$ \\
\hline
\end{tabular}

Table 2. Effect of various concentrations of $\mathrm{NaCl}$ and $\mathrm{Na}_{2} \mathrm{SO}_{4}$ on alkaloid contents of Datura metel $\mathrm{L}$.

\begin{tabular}{|c|c|c|c|}
\hline $\begin{array}{l}\text { Trea tme nts } \\
(\mathrm{mM})\end{array}$ & $\begin{array}{c}\text { Alkaloids } \\
\text { mg/100gm.D.Wt. }\end{array}$ & Treatments (mM) & $\begin{array}{c}\text { Alkaloids } \\
\text { mg/100gm.D.Wt. }\end{array}$ \\
\hline Control & 279.50 & & 279.50 \\
\hline $\mathrm{NaCl} 2.5$ & 312.25 & $\mathrm{Na}_{2} \mathrm{SO}_{4} 2.5$ & 281.45 \\
\hline 5.0 & 327.10 & 5.0 & 301.90 \\
\hline 7.5 & 325.11 & 7.5 & 288.62 \\
\hline 10.0 & 275.24 & 10.0 & 269.77 \\
\hline 12.5 & 268.89 & 12.5 & 254.39 \\
\hline 15.0 & 257.55 & 15.0 & 233.39 \\
\hline 17.5 & 233.67 & 17.5 & 214.20 \\
\hline 20.0 & 211.14 & 20.0 & 198.12 \\
\hline
\end{tabular}

\section{Conclusion:}

From the results it is clear that Datura metel L. require salts for its growth. Its callus could be grown with more productivity up to 7.5 $\mathrm{mM}$ of both the salts. The results indicate that, stress induced by $\mathrm{NaCl}$ and $\mathrm{Na}_{2} \mathrm{SO}_{4}$ is favourable for alkaloid production up to certain levels.

\section{Acknowledgement:}

Author gratefully acknowledges the receipt of financial assistance received from UGC (New Delhi). 


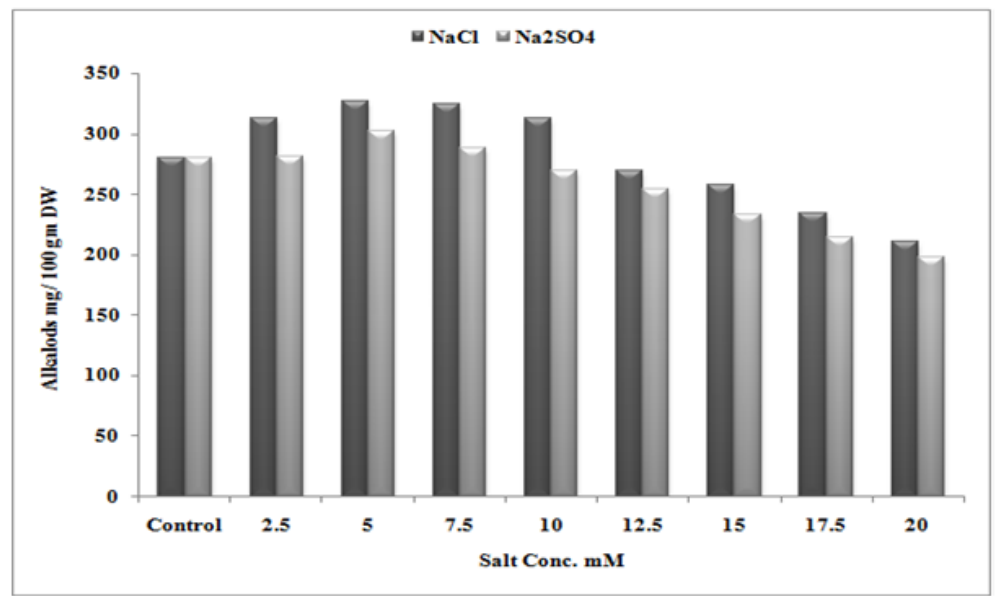

Figure 1. Average total alkaloid conte nt in callus of Datura under $\mathrm{NaCl}$ and $\mathrm{Na}_{2} \mathrm{SO}_{4}$.

\section{References:}

De, K. K. (2004). An introduction to plant tissue culture. New Central Book Agency (P) Ltd., Calcutta.

Freeman, F. M. (1955). New reagents for the colorimetric determination of atropa alkaloids. Analyst., $80: 520-522$.

Jaggi, R. K., Quadri, J.S. and Kapoor, V. K. (1989). Tissue culture techniques in the production of secondary metabolites of the plant of the solanaceae. Indian Drugs. 27(5): 270-280.

Murashige, T. and Skoog, F. (1962). A revised medium for growth and bioassays with tobacco tissue culture. Plant Physiol. 15: 437-497.

Muthukumar, B., Aroekiasamy, D. I. and John, B. S. (2001). Response of explants of $D$. metel L. to different types of auxins and cytokinins in LS and MS medium . J. of Physiol. Res. 14(1): 13-18.

Trease, G. E. and Evans, W.C. (1985). Pharmacognosy. Twelfth ELBS Ed. 